\title{
Evaluation of heavy metals in some selected medicinal plants growing within the University of Ibadan Campus
}

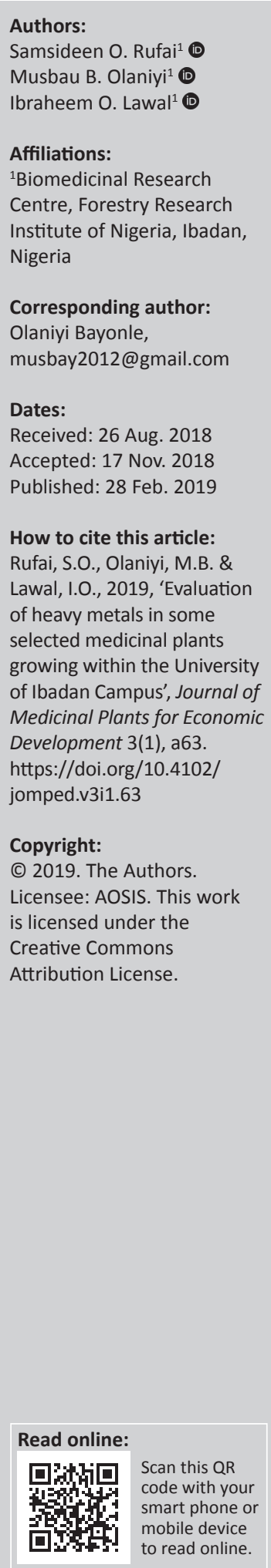

Background: Medicinal plants are a potent source of therapeutic molecules that heal various diseases in the world.

Aim: The aim of this study was to evaluate heavy metal concentrations in the leaves of some selected medicinal plants in selected locations.

Setting: The leaves of Azadirachta indica, Magnifera indica and Newbouldia laevis were collected from the botanical garden, roadside and residential area in the University of Ibadan and were authenticated at the Forest Herbarium Ibadan. The samples were thoroughly washed with deionised water and air-dried at room temperature for about three weeks, then ground into powder with a mechanical grinder. The samples were subsequently stored in air-tight bottles for further work.

Methods: The milled samples were subjected to wet digestion, and then lead $(\mathrm{Pb})$, chromium $(\mathrm{Cr})$, cadmium $(\mathrm{Cd})$ and nickel $(\mathrm{Ni})$ were analysed using standard methods.

Results: The results obtained show that the highest concentrations of $\mathrm{Pb}, \mathrm{Cr}$ and $\mathrm{Cd}$ in the medicinal plants studied were found in N. laevis (23.93 ppm; road side), N. laevis (4.79 ppm; road side) and $M$. indica ( $0.36 \mathrm{ppm}$; road side), respectively, while the lowest concentrations of $\mathrm{Pb}, \mathrm{Cr}$ and $\mathrm{Cd}$ were found in $\mathrm{A}$. indica $(7.10 \mathrm{ppm}$; botanical garden), N. laevis (0.73 ppm; residential) and $\mathrm{N}$. laevis (0.05 ppm; residential), respectively. Ni was totally undetected in all three medicinal plants studied in all the locations.

Conclusion: The concentrations of heavy metals at the roadside and residential area were higher than permissible limits set for medicinal plants, but the botanical garden was the lowest and safest in terms of heavy metals accumulation in the medicinal plants studied in the three locations.

\section{Introduction}

The consumption of medicinal plants for therapeutic purposes is recognised as one of the earliest forms of medical practice of mankind. The World Health Organization reported that $80 \%$ of the emerging world's population, both in developed and developing countries, relies on traditional medicine for therapy (WHO 2004). The high demand for traditional and alternative medicines has led to a rapid increase in the medicinal plant product market worldwide (WHO 2007). Natural products from plants and their derivatives represent more than $25 \%$ of all drugs currently in clinical use by Gurib-Fakim (2006). However, there is a misconception that 'natural' always means 'safe' and that remedies from a natural origin are harmless and carry no risk. But 'natural' plant-based medicines are not always safe because there is the tendency that plant samples may be contaminated with hazardous substances such as toxic heavy metals, agrochemicals and pathogenic microorganisms (WHO 2004).

In recent decades, heavy metals have been used widely to refer to a group of metals that are associated with contamination and potential toxicity with no clear and unique scientific definition (Duffus 2002). Heavy metals do not undergo biodegradation and thus are accumulated in living organisms, leading to various diseases and disorders even in relatively low concentrations as confirmed by Pehlivan et al. (2009). Plants usually take up trace elements and heavy metals that are dissolved in soil solutions in ionic, chelated or complexed forms (Kabata-Pendias 2011). Accumulation of toxic metals in medicinal plant products is becoming a major concern in traditional medicine. One of the major means of heavy metal accumulation in medicinal plants is through the uptake and accumulation of toxic metals and trace elements that are inherently 
present in the soil. Heavy metals, such as iron, chromium, copper, zinc, cobalt, manganese and nickel, are essential metals that play an important role in biological systems, whereas mercury, lead and cadmium are non-essential metals that can be toxic even in trace amounts. Lead, cadmium, chromium and arsenic are widely considered as potential contaminants in our environment (Mosihuzzanman \& Chowder 2008). All plants contain heavy metals in trace or negligible amounts as micronutrients, and when the uptake of heavy metals become greater, they contaminate the environment, thus leading to adulterated food supply (Abdollatif et al. 2009). The contamination of medicinal plants by heavy metals can be attributed to environmental pollution and can pose clinically relevant dangers for the health of the consumer, and should therefore be limited (Salaramoli et al. 2012; Ullah et al. 2012). These metals have the potential to accumulate in different organs of the body for a long period of time as some of them possess longer biological half-lives that cause toxicities and unwanted effects (Ata, Moore \& Modabberi 2009; Jarup 2003). Khan et al. (2008) also reported that, after collection and transformation of medicinal plants into dosage form, the heavy metals confined in them finally enter the human body and may impair the normal functions of vital organs, leading to hypertension, abnormal pain, skin eruption, intestinal ulcers and different types of cancers. High levels of heavy metals in the body system cause common health problems, as reported in the study by Hussain and Khan (2010).

The problem is more serious in Nigeria because medicinal plants that form the raw materials for the finished product of herbal treatment are neither controlled nor properly regulated by quality assurance parameters. The WHO recommends that medicinal plants that form the raw materials for the finished products may be checked for the presence of heavy metals. According to Khan et al. (2008), the maximum permissible limits of toxic metals like arsenic, cadmium and lead in consumed medicinal plants are $1.0 \mathrm{ppm}, 0.3 \mathrm{ppm}$ and 10 ppm, respectively.

The ability of plants to selectively accumulate essential elements varies in different species and is subjected to certain geographical characteristics depending on the type of soil (Khan et al. 2008). Because of these health problems, the World Health Organization is advising that herbal drugs should not be used without qualitative and quantitative analysis of their heavy metals content (WHO 2005). However, evaluating and monitoring heavy metal contamination is an essential step in improving the overall safety and quality of widely used medicinal plants, which will in turn result in safeguarding the consumer (Street et al. 2008). From the literature, it has been reported that various parts, such as leaves, stems, barks, fruits and roots of Azadirachta indica, Mangifera indica and Newbouldia laevis, possess several biological properties (antioxidant, anti-inflammatory, antidiabetic, anti-malarial, anti-fungal and anti-bacterial), which are used for the treatment of various ailments in humans. Thus, this study evaluates the concentration of heavy metals in some selected medicinal plants within three different locations at the University of Ibadan with the aim of determining the safety and quality of these medicinal plants.

\section{Materials and methods Study area}

This study was carried out at the University of Ibadan, which is located on the latitude $9^{\circ} 23^{\prime} 28.19^{\prime \prime} \mathrm{N}$ and longitude $3^{\circ} 5459.99^{\prime \prime E}$ and characterised by dry and rainy seasons. The rainy season starts from late March to October, with a mean annual rainfall of approximately $1200 \mathrm{~mm}$ and a double maxima rainfall with a peak in June, which is interrupted by a short break and a second peak in September. The dry season, usually from November to March, is brought about by the north-east trade winds. The relative humidity is very high during the rainy season and very low during the dry season. The mean annual temperature ranges from $21^{\circ} \mathrm{C}$ to $26^{\circ} \mathrm{C}$.

\section{Sample collection and preparation}

The leaves of $A$. indica, $M$. indica and $N$. laevis were obtained from 27 trees of height between $1.5 \mathrm{~m}$ and $3 \mathrm{~m}$ and diameter at breast height (DBH) between $15 \mathrm{~cm}$ and $30 \mathrm{~cm}$. The leaves were cut off from all around the crown periphery in nine trees per location, with every three trees representing each of the selected species collected from three different locations within the University of Ibadan Campus (botanical garden, roadside and residential area) and authenticated at the Taxonomy Section and Biomedicinal Research Centre of Forestry Research Institute of Nigeria, Ibadan. The samples were thoroughly washed with deionised water and airdried at room temperature for about three weeks and then ground into powder with a mechanical grinder and homogenised. The powdered, samples were stored in airtight bottles for analysis.

\section{Wet digestion procedure}

The digestion of samples was carried out according to the standard procedure described by Okalebo, Catha and Woomer (2002). One gram of the samples was digested with $5 \mathrm{~mL}$ of $16 \mathrm{M} \mathrm{HNO}_{3}$ in the covered beakers to near dryness, and another $5 \mathrm{~mL}$ essential portion of $16 \mathrm{M} \mathrm{HNO}_{3}$ was further added until the sample solutions became clear. Five millilitres of $12 \mathrm{M} \mathrm{HCl}$ was then added to ensure complete digestion and then cooled to room temperature. The digested solutions were diluted to $100 \mathrm{~mL}$ with deionised water. The samples were analysed using atomic absorption spectrophotometer (AAS) for the concentrations of lead, chromium, cadmium and nickel.

\section{Calibration of equipment}

The following sensitivity and detection limits were established for the elements (lead, chromium, cadmium and nickel) under investigation using AAS: lead 0.5 ppm - 2.5 ppm, chromium 0.5 ppm - 2.5 ppm, cadmium 0.2 ppm - 1.0 ppm and nickel $2.0 \mathrm{ppm}-10.0 \mathrm{ppm}$. 


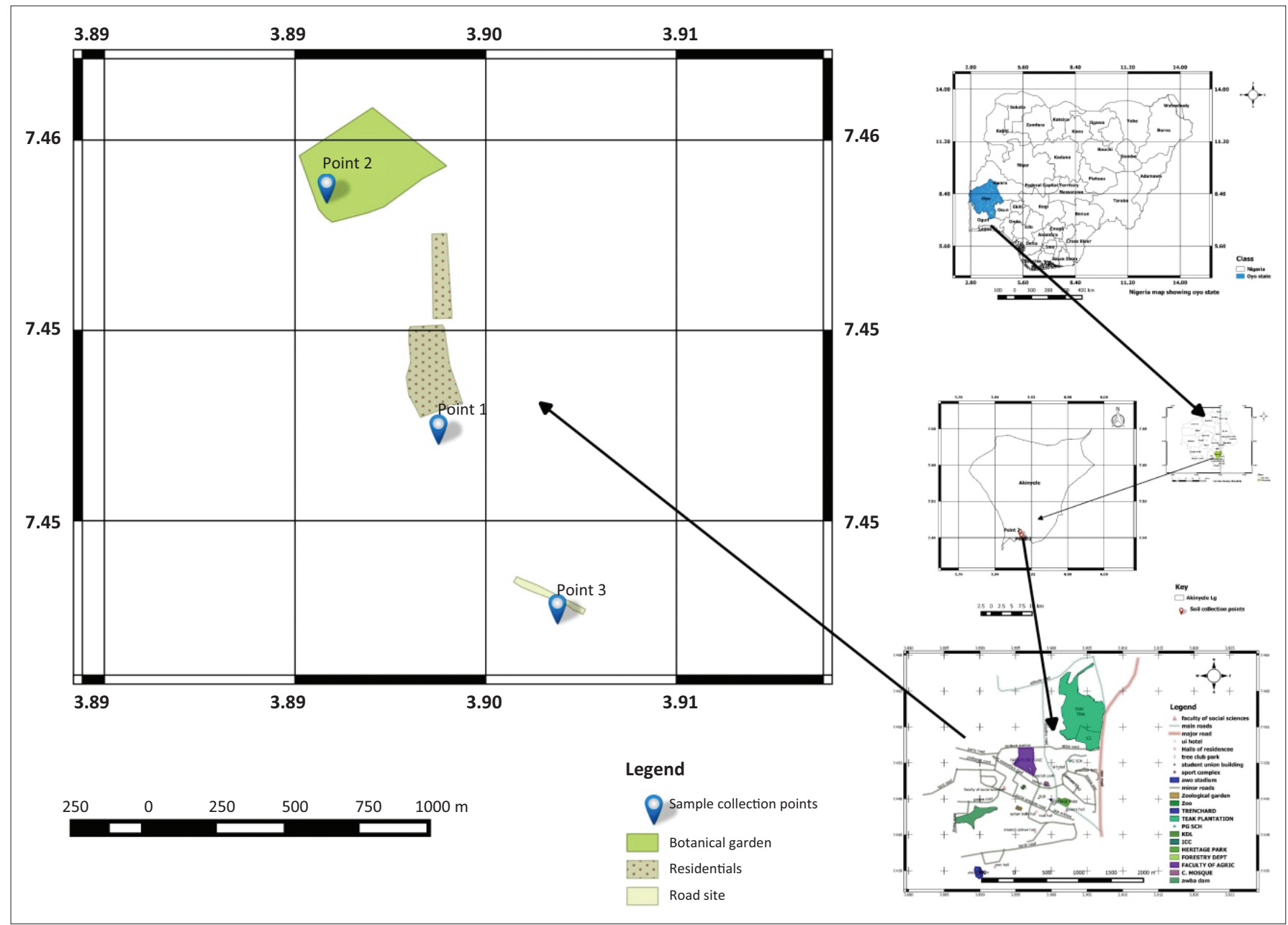

FIGURE 1: Map showing the three locations where samples of leaves were collected.

\section{Preparation of blank solutions}

The stock solution for $\mathrm{Pb}, \mathrm{Cr}, \mathrm{Cd}$ and $\mathrm{Ni}$ was made from a metal salt of Analar grade (purity 99.9\%). The metal salt was dissolved in dilute $\mathrm{HCl}$ and diluted to the $1 \mathrm{~L}$ mark using distilled water. The required concentrations were prepared by several dilution of the stock solution.

\section{Statistical analysis}

All data obtained were statistically analysed using the two-way analysis of variance (ANOVA). The data were expressed as mean \pm standard deviation. The mean was tested for significance at 5\% level $(p<0.05)$ using Duncan Multiple Range Test.

\section{Ethical statement}

Human rights, conflict of interest, safety and health standards, and plagiarism were duly considered in this research.

\section{Results and discussion \\ Results}

The analyses of the levels of heavy metals present in the selected medicinal plants revealed that nickel was not detected in the three medicinal plants investigated, and the
TABLE 1: Lead concentration (ppm) in selected medicinal plants across locations within the University of Ibadan.

\begin{tabular}{lccc}
\hline $\begin{array}{l}\text { Location of } \\
\text { plant sample }\end{array}$ & $\begin{array}{c}\text { Azadirachta } \\
\text { indica }\end{array}$ & $\begin{array}{c}\text { Mangifera } \\
\text { indica }\end{array}$ & $\begin{array}{c}\text { Newbouldia } \\
\text { laevis }\end{array}$ \\
\hline Road side & $11.8 \pm 0.04^{\mathrm{e}}$ & $11.60 \pm 0.07^{\mathrm{e}}$ & $23.93 \pm 0.07^{\mathrm{f}}$ \\
Residential & $11.20 \pm 0.31^{\mathrm{d}}$ & $9.91 \pm 0.10^{\mathrm{c}}$ & $11.03 \pm 0.07^{\mathrm{d}}$ \\
Botanical garden & $8.22 \pm 0.06^{\mathrm{b}}$ & $7.10 \pm 0.14^{\mathrm{a}}$ & $8.28 \pm 0.27^{\mathrm{b}}$ \\
\hline
\end{tabular}

Note: Superscripts a-f show the level of differences among the mean values. Values expressed as mean \pm standard deviation with same superscript are not significantly different from each other across the rows and columns.

concentrations (ppm) of lead, chromium and cadmium are presented in Tables 1, 2 and 3, respectively. Results obtained further show that lead $(7.10 \pm 0.14 \mathrm{ppm}-23.4 \pm 0.07 \mathrm{ppm})$ was the most abundant element in the three samples investigated, followed by chromium $(0.73 \pm 0.14 \mathrm{ppm}$ $-4.79 \pm 0.33 \mathrm{ppm})$, and the lowest concentration of cadmium $(0.05 \pm 0.01 \mathrm{ppm}-0.36 \pm 0.03 \mathrm{ppm})^{1}$ was found. From the overall results obtained in this study, it implies that concentration of any heavy metal accumulation in any medicinal plants is dependent on the plant species and locations from where samples are collected. The cleaner the location, the lower the concentration of heavy metals will be in the plant sample.

1.The significance for the superscript letters (a, b, c, etc.) used along with values here and elsewhere is to show that the medicinal plants studied were significantly varied and elsewhere is to show that the medicinal plants studied were significantly varied
from one another in terms of heavy metal accumulation across the sources. It also represents the level of significance. 


\section{Lead}

Among the three medicinal plants studied across all the locations, the highest concentration (ppm) of lead was found in N. laevis $(23.93 \pm 0.07 \mathrm{ppm})$, followed by $A$. indica $(11.8 \pm 0.04 \mathrm{ppm})$, and the lowest concentration was found in M. indica $(7.10 \pm 0.14)$ (Table 1$)$.

\section{Chromium}

The highest concentration (ppm) of chromium in the medicinal plants studied was found in N. laevis $(4.79 \pm 0.33 \mathrm{ppm})$ among the three samples across all three sample locations, which was also the highest among the three plant samples obtained from road side, residential area and botanical garden, followed by $M$. indica $(3.43 \pm 0.05 \mathrm{ppm})$, and surprisingly the lowest concentration was also found in $N$. laevis $(0.73 \pm 0.14 \mathrm{ppm})$ among samples from road side and residential area. Also, chromium was not detected in N. laevis and $M$. indica collected from the botanical garden (Table 2).

\section{Cadmium}

The results revealed that the highest concentration (ppm) of cadmium in the selected medicinal plants studied was found in $M$. indica $(0.36 \pm 0.03 \mathrm{ppm})$ among all the three samples across the three sample locations, followed by A. indica $(0.12 \pm 0.01 \mathrm{ppm})$, and the lowest concentration was found in $N$. laevis $(0.05 \pm 0.01 \mathrm{ppm})$. However, cadmium was not detected in the three medicinal plant samples collected from the botanical garden at all and was also not detected in $A$. indica and $N$. laevis collected from the road side and $M$. indica collected from the residential area (Table 3).

\section{Discussion}

\section{Lead}

Lead is a non-essential trace element that functions neither in human body nor in plant. It causes both acute and chronic poisoning that pose adverse effects on the vital organs such as kidney, liver, vascular and body immune system (Jabeen et al. 2010; Moses et al. 2012). According to Khan et al. (2008),

TABLE 2: Chromium concentration (ppm) in selected medicinal plants across locations within the University of Ibadan.

\begin{tabular}{lccc}
\hline $\begin{array}{l}\text { Location of } \\
\text { plant sample }\end{array}$ & $\begin{array}{c}\text { Azadirachta } \\
\text { indica }\end{array}$ & $\begin{array}{c}\text { Mangifera } \\
\text { indica }\end{array}$ & $\begin{array}{c}\text { Newbouldia } \\
\text { laevis }\end{array}$ \\
\hline Road side & $3.02 \pm 0.08^{\mathrm{e}}$ & $3.43 \pm 0.05^{\mathrm{f}}$ & $4.79 \pm 0.33^{\mathrm{g}}$ \\
Residential & $2.26 \pm 0.02^{\mathrm{d}}$ & $1.17 \pm 0.06^{\mathrm{b}}$ & $0.73 \pm 0.14^{\mathrm{a}}$ \\
Botanical garden & $1.97 \pm 0.09^{\mathrm{c}}$ & $\mathrm{ND}$ & $\mathrm{ND}$ \\
\hline
\end{tabular}

Note: Superscripts a-g show the level of differences among the mean values. Values expressed as mean \pm standard deviation with same superscript are not significantly different from each other across the rows and columns.

ND, not detected.

TABLE 3: Cadmium concentration (ppm) in selected medicinal plants across locations within the University of Ibadan.

\begin{tabular}{lccc}
\hline $\begin{array}{l}\text { Location of } \\
\text { plant sample }\end{array}$ & $\begin{array}{c}\text { Azadirachta } \\
\text { indica }\end{array}$ & $\begin{array}{c}\text { Mangifera } \\
\text { indica }\end{array}$ & $\begin{array}{c}\text { Newbouldia } \\
\text { laevis }\end{array}$ \\
\hline Road side & ND & $0.36 \pm 0.03^{\mathrm{c}}$ & ND \\
Residential & $0.12 \pm 0.01^{\mathrm{b}}$ & $\mathrm{ND}$ & $0.05 \pm 0.01^{\mathrm{a}}$ \\
Botanical garden & $\mathrm{ND}$ & $\mathrm{ND}$ & $\mathrm{ND}$ \\
\hline
\end{tabular}

Note: Superscripts a-c show the level of differences among the mean values. Values expressed as mean \pm standard deviation with same superscript are not significantly different from each other across the rows and columns.

ND, not detected. some of the noticeable symptoms of lead poisoning include colic, anaemia, headache, brain damage, central nervous system disorders, convulsion and chronic nephritis of the kidney. From this study, it shows that the highest concentration of lead was found in N. laevis (23.93 ppm) growing along the road side of the study area and the lowest concentration was observed in $M$. indica (7.10 ppm) growing in the botanical garden. The highest lead concentration found can be attributed to a high number of vehicles and commercial activities at the road side, while the lowest concentration may be because of the reduced level of human activities and restriction of vehicles into the botanical garden. This result is in agreement with the earlier findings of Bankole et al. (2014), which reported high levels, of heavy metal contamination at the road side and low levels, of contamination at a control site far away from the road side. According to WHO (2005), the permissible limit for lead content in medicinal plant and herbal medicine is $10 \mathrm{ppm}$ and the dietary intake limit for lead is $3 \mathrm{mg}$ / week, which is also the standard limit set by the Chinese, Malaysian and Thai government (Moses et al. 2012). A further comparison of the result obtained from this study with the WHO/FAO prescribed limit showed that all three medicinal plant samples (A. indica, $M$. indica and N. laevis) from the botanical garden and only $M$. indica sample from the residential area are within the permissible limit and are therefore safe for consumption, but the remaining samples (A. indica, M. indica and N. laevis), especially from the road side, show levels far higher than the permissible limit and it should hence not be consumed as it might be injurious to human health. In addition, all three medicinal plants are significantly different from one another in terms of the levels of lead accumulated in each of the medicinal species studied across the locations (Table 1).

\section{Chromium}

Gajalakshmi et al. (2012) reported that chromium is considered a serious environmental pollutant despite its wide industrial use. It is not directly absorbed by plants but accumulated by carrier ions like sulphate or iron. Exposure to chromium might result in liver, kidney and lungs damage (Khan et al. 2008). Results obtained showed that the highest concentration of chromium was found in N. laevis (4.79 ppm), followed by $M$. indica (3.43 ppm) at the road side and surprisingly the lowest concentration of chromium was also found in $N$. laevis (0.73 ppm) in the residential area. However, chromium was detected only in A. indica (1.97 ppm) at the botanical garden. This corroborates the result of Gajalakshmi et al. (2012), which reported the presence of chromium and other heavy metals in some medicinal plants in Kenya and also stated that heavy metal contamination could be attributed to overusage of fertiliser, industrial effluent dropout and other manmade activities that were not practised in the botanical garden. Moses et al. (2012) reported that the permissible limit set by WHO/FAO for chromium has not been well established, but the permissible limit set by the Canadian government was 2.0 ppm in raw medicinal plants. The comparison of this permissible limit with the results obtained indicated that all three medicinal plants 
from the road side and only $A$. indica from the residential area exceeded the prescribed limit. At the botanical garden, where chromium is only present in A. indica, the concentration of chromium is below the permissible limit. Consequently, the result revealed that it is not encouraging to consume medicinal plants at the road side and only botanical garden samples are safe for consumption. However, Khan et al. (2008) reported that the intake of chromium might result in ailments such as skin rashes, nose irritation, nasal itches, bleeding, stomach upset, lung cancer, as well as kidney and liver damage. Also, all three medicinal plants are significantly different from one another in terms of chromium concentration across the three locations (Table 2).

\section{Cadmium}

Jabeen et al. (2010) reported that cadmium causes both severe and chronic poisoning, which may result in adverse effects on the kidney, liver, vascular and immune system. Results obtained revealed that cadmium was totally undetected in all three medicinal plants (A. indica, M. indica and N. laevis) from the botanical garden but present only in $M$. indica in the highest concentration of $0.36 \mathrm{ppm}$ at the road side. In the residential area, cadmium was found in $A$. indica (0.12 ppm) and $N$. laevis $(0.05 \mathrm{ppm})$, respectively. In addition, the permissible limit for cadmium set by WHO/FAO (0.3 ppm) is similar to the limit prescribed by the governments of China, Thailand and Canada in raw medicinal plant materials, and $0.006 \mathrm{mg} /$ day in finished herbal products. This implies that the three medicinal plants in the botanical garden as well as N. laevis and A. indica in the residential area are safe to serve as raw materials for a herbal formulation or drug. Comparison of the results obtained from this study indicated that only $M$. indica (mango leaves) at the road side exceeded the prescribed limit, while all others fell below the permissible standard set by WHO/FAO. Furthermore, all three medicinal plants were significantly different from one another in terms of cadmium concentration accumulated in each of the three locations (Table 3).

\section{Nickel}

Nickel is required in the body in minute quantities as it is present in the pancreas where it plays an important role in insulin production. However, nickel has been identified as a suspected carcinogen, and it adversely affects lungs and nasal cavities. Jabeen et al. (2010) revealed that the toxicity of nickel in the human body is not very common because the body absorbs it at a very slow rate. Also, Khan et al. (2008) confirmed that the deficiency of nickel in the human body results in liver disorder. From the results of this study, it was observed that nickel was totally undetected in all the selected medicinal plants investigated across the three locations.

\section{Conclusion}

The results of this study confirmed that the samples of leaves of the selected medicinal plants ( $M$. indica, A. indica and $N$. laevis) contain varying quantities of heavy metals across the three locations (road side, residential area and botanical garden) in the University of Ibadan. The concentration (ppm) of the heavy metals found was lead (7.10 ppm - 23.93 ppm), chromium (0.73 ppm - 4.79 ppm), cadmium (0.05 ppm - $0.36 \mathrm{ppm})$, and nickel was totally absent in all the samples studied. On comparison of the results obtained to the permissible limits set by the WHO/ FAO, it was concluded that plants growing at the road side contain heavy metals above the prescribed level; reduced levels were found in those growing in the residential area; and below prescribed were found levels in the plants in the botanical garden where human activities are minimal. This level of contamination could be attributed to vehicle emission and anthropogenic activities, and therefore consideration should be given to the place of collection for medicinal plants for therapeutic purposes.

\section{Acknowledgements}

The authors thank Mr Emmanuel Chuwkuma of Forest Herbarium Ibadan, Forestry Research Institute of Nigeria, and Dr S.O. Olajuyigbe of the Department of Forest and Forest Products, University of Ibadan, for their immense contributions towards achieving this scholarly research work.

\section{Competing interests}

The authors declare that they have no financial or personal relationships which may have inappropriately influenced them in writing this article.

\section{Authors' contributions}

S.O.R. designed the study, coordinated plant material collection and storage, carried out all the experiments and drafted the manuscript. I.O.L. was responsible for the plant identification, supervised the laboratory experiments and made substantial contributions to revise the manuscript critically. M.B.O. was responsible for the preparation of samples, data analysis and manuscript editing. All authors read and approved the final manuscript.

\section{References}

Abdollatif, G.A., Ardalan, M., Mohammadi, M.T., Hosseini H.M. \& Karimian, M., 2009, 'Solubility test in some phosphate rocks and their potential for direct application in soil', World Applied Science Journal 6, 182-190.

Ata, S., Moore, F. \& Modabberi, S., 2009, 'Heavy metal contamination and distribution in the Shiraz Industrial Complex Zone soil, South-Shiraz, Iran', World Applied Science Journal 6, 413-425.

Bankole, S.O., Ogunbamowo, P.O., Bankole, R.T., Awotedu, O.O \& Odewale, M.O., 2014, 'Heavy metal levels in Amaranthus hybridus cultivated on soil samples collected from selected industrial sites in Ibadan', A conference paper presented at The $49^{\text {th }}$ Annual Conference of Science Association of Nigeria held 27th April 1 st May at the University of Ilorin Auditorium, llorin, Nigeria.

Duffus, J.H., 2002, “'Heavy metals", a meaningless term (IUPAC Technical Report)', Pure and Applied Chemistry 74, 793-807. https://doi.org/10.1351/pac200274050793

Gajalakshmi, S., Iswarya, V., Ashwini, R., Divya, G., Mythili, S. \& Sathiavelu, A., 2012, 'Evaluation of heavy metals in medicinal plants growing in Vellore district', European Journal of Experimental Biology 2(5), 1457-1461, ISSN: 2248-9215.

Gurib-Fakim, A., 2006, 'Medicinal plants: Tradition of yesterday and drugs of tomorrow', Molecular Aspect of Biology 27, 1-9. https://doi.org/10.1016/j.mam.2005.07.008

Hussain, I. \& Khan, H., 2010, 'Investigation of heavy metals content in medicinal plant (Eclipta alba L.)', Journal of the Chemical Society of Pakistan 32, 28-33.

Jabeen, S., Shah, M.T., Khan, S. \& Hayat, M.Q., 2010, 'Determination of major and trace elements in ten important folk therapeutic plants of Haripur basin, Pakistan', Journal of Medicinal Plants Research 4(7), 559-566. 
Jarup, L., 2003, 'Hazards of heavy metals contamination', British Medical Bulletin 68, 167-182. https://doi.org/10.1093/bmb/ldg032

Kabata-Pendias, A., 2011, Trace elements in soils and plants, 4th edn., CRC Press, Boca Raton, FL, pp. 287-300.

Khan, S.A., Khan, L., Hussain, I., Marwat, K.B. \& Ashtray, N., 2008, 'Profile of heav metals in selected medicinal plants', Pakistan Journal of Weed Science Research 14(1-2), 101-110.

Moses, A.G., Maobe, E.G., Leonard, G. \& Henry, R., 2012, 'Profile of heavy metals in selected medicinal plants used for the treatment of diabetes, malaria and pneumonia in Kisii region, Southwest Kenya', 'Global Journal of Pharmacology 6(3), 245-251, ISSN 1992-0075.

Mosihuzzanman, M. \& Chowder, M.I., 2008, 'Product on safety, efficiency, standardization and documentation of herbal medicine'. Pure Applied Chemistry 80(10), 2195-2230. https://doi.org/10.1351/pac200880102195

Okalebo, J.R., Catha, K.W. \& Woomer, P.L., 2002, Laboratory methods of soil and plant analysis: A working manual, TSBF-CIAT and Sacred Africa, Nairobi, Kenya, p. 200.

Pehlivan, E., Özkan, A.M., Dinç, S. \& Parlayici, S., 2009, 'Adsorption of Cu2+ and Pb2+ ion on dolomite powder', Journal of Hazardous Materials 167, 1044-1049. https:// doi.org/10.1016/j.jhazmat.2009.01.096
Salaramoli, J., Salamat, N., Najafpour, S.H., Hassan, J. \& Aliesfahani, T. 2012, 'The determination of total mercury and methyl mercury contents of oily white and light style of Persian Gulf Tuna Cans', World Applied Sciences Journal 16(4), and light sty

Street, R.A., Kulkarni, M.G., Stirk, W.A., Southwayand, C. \& Van Staden, J., 2008 'Variation in heavy metals and microelements in South African medicinal plants obtained from street markets', Food Additives, Contaminants. Part. A. Chemistry, Analysis, Control Exposure Risk Assessment 25, 953-960. https://doi.org/10.1080/ Analysis, Control Exposur

Ullah, R., Khader, J.A., Hussain, I, AbdElsalam, N.M., Talha, M. \& Khan, N., 2012 'Investigation of macro micro-nutrients in selected medicinal plants', African Journal of Pharmacy and Pharmacology 6(25), 1827-1832.

World Health Organisation, 2004, WHO guidelines on safety monitoring of medicina plant products in pharmaco-vigilance systems, Geneva, Switzerland.

World Health Organisation, 2005, Working document QAS/05.131/Rev.1, quality control methods for medicinal plant material, Geneva, Switzerland, pp. 20-27.

World Health Organization, 2007, WHO guidelines for assessing quality of medicinal plant products with reference to contaminants and residues, Geneva, Switzerland. 